Anne Kärki, Seliina Päällysaho, Jaana Latvanen,

Hannu Hyyppä ja Pauli Assinen

\title{
AVOIN TOIMINTAKULTTUURI YHDESSÄ KÄYTTÖÖN - OPEN SCIENCE 2020 BERLIINISSÄ
}

Maaliskuun puolivälissä pidetty Open Science 2020 -konferens-

si kokosi seitsemättä kertaa yhteen avoimen tieteen parissa toimivia eri puolilta akateemista maailmaa. Konferenssi typistyi koronaviruspandemian takia yksipäiväiseksi, mutta onnistui silti antamaan hyvän kuvan avoimen tieteen tilasta Euroopassa. Samalla tuli ilmi myös haasteet, jotka liittyivät ennen muuta avoimuuden kannustimiin, tutkimusprosessien läpinäkyvyyteen ja tutkimusaineistojen potentiaalin hyödyntämiseen.

Seitsemättä kertaa järjestetty Open tanut suomalaisia asiantuntijoita Science 2020 -konferenssi keräsi yli laajasti, esimerkiksi vuonna 2019 suo200 osallistujaa Euroopasta ja muualta malaisia oli konferenssissa kymmenmaailmasta. Mukana oli tieteen ja tut- kunta.

kimuksen avoimuudesta kiinnostunei- Tänä vuonna poikkeusolosuhteita eri alojen asiantuntijoita ja tutkijoita, den takia tapahtuma toteutui lopulta kirjastoalan ammattilaisia, tukipalvelu- suunnitelmista poiketen yksipäiväijen tarjoajia sekä päättäjï. Tapahtuman senä, kun konferenssin jälkimmäinen järjestivät tuttuun tapaan saksalaiset tut- päivä peruttiin nopealla aikataululla kimusorganisaatiot Leibniz Research Al- edellisenä iltana. Konferenssin ohjelma liance ja Leibniz Information Centre for striimattiin reaaliaikaisesti verkkoon ja Economics (zBw). osa jälkimmäiselle päivälle suunnitel-

Tänä vuonna koronapandemiatilan- luista esityksistä on edelleen katsotne verotti etenkin skandinaavisia osallistujia ja paikan pällle saapuneita suomalaisia osallistujia oli tilaisuudessa vain kaksi yliopisto- ja ammattikorkeakoulusektorista. Aikaisempina vuosina konferenssi on kiinnostavissa konferenssin nettisivuilla.

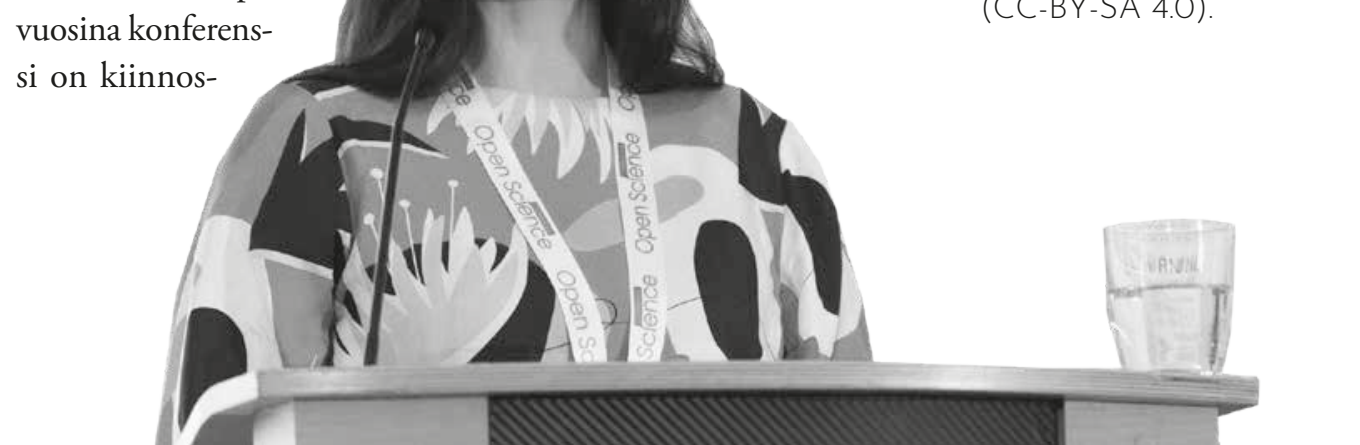

Seliina Päällysaho SeAMKista esitteli hyviä käytänteitä liittyen yritysyhteistyöprojekteihin. Kuva: Ralf Rebmann (CC-BY-SA 4.O). 


\section{Posterit esittelivät uusimpia tuulia}

Vakiintuneena osana konferenssin ohjelmaa järjestettiin posteri- ja verkostoitumissessio. Tänä vuonna postereissa haluttiin esitellä etenkin innovatiivisia avoimen tieteen ratkaisuja, empiirisiä case-tutkimuksia sekä avoimen tieteen ja tutkimuksen koulutukseen ja viestintään liittyviä hyviä käytänteitä.

Konferenssiin ehdotetusta 65 posteriabstraktista hyväksyttiin vertaisarvioinnin perusteella mukaan 20 posteria. Suurin osa esillä olleista postereista oli melko käytännönläheisiä ja ne esittelivät avointa tiedettä ja tutkimusta etenkin eurooppalaisesta näkökulmasta. Mukana oli niin case-kuvauksia yksittäisistä palveluista ja niiden tarjoamista mahdollisuuksista kuin myös laajempia koko tutkimusekosysteemin avoimuutta tukevien prosessien kuvailuja.

Useassa posterissa ja esityksessä esiteltiin EU-rahoitteisia projekteja ja niihin liittyviä työpaketteja. Näyttääkin siltä, että monet korkeakoulut ja tutki- muslaitokset panostavat voimakkaasti avointa tiedettä ja tutkimusta tukevien käytänteiden kehittämiseen. Työtä tehdään moninaisten digitaalisten työkalujen, työskentelytapojen, tekniikoiden sekä tulevaisuuden suuntien kehittämisessä ja niitä eteenpäin ajavien voimien ja esteiden kartoittamisessa.

Suomalaisten ammattikorkeakoulujen yhteinen, opetus- ja kulttuuriministeriön rahoittama, Ammattikorkeakoulujen Avoin TKI, oppiminen ja innovaatioekosysteemi -hanke oli konferenssissa hyvin edustettuna kahden posterin kautta. Developing Open RDI and Education -posteri toi esille avoimeen TKI-toimintaan ja oppimiseen liittyviä osaamisvajeita ja tukipalvelutarpeita. Perspectives on the Nature of Open Data in Business Cooperation -posteri kuvasi avoimien 
yritysyhteistyöprojektien esteitä ja parhaita käytäntöjä. Kyseinen posteri pääsi myös niiden kahdeksan parhaan posterin joukkoon, jotka saivat puheenvuoron ensimmäisen konferenssipäivän Short talks -osuudessa.

\section{Strategisesti kohti avoimuutta}

Konferenssin avasi professori Klaus Tochtermann zBw:stä. Hänen mukaansa nyt on korkea aika siirtyä sanoista konkreettisiin tekoihin. Erityisen tärkeää on nostaa esiin esimerkkejä siitä, miten jo kehitettyjä työkaluja ja toimintatapoja voidaan hyödyntää tehokkaasti, ja mitä lisäarvoa ne voivat tuoda päivittäisiin rutiineihin. Fokus tulee siis kohdistaa nyt varsinaiseen tekemiseen.

Viime vuosien aikana eurooppalaisessa kontekstissa on saatu valmiiksi useita avoimuutta tukevia infrastruktuureja, palveluja sekä strategioita. Tutkijat eivät kuitenkaan ole ottaneet palveluja ja infrastruktuureja laajasti käyttöön. Sama on havaittavissa suomalaisessa tutkimusyhteisössä.

Useissa esityksissä nousi esiin yhteistyön merkitys ja se, kuinka päämääriin yltäminen edellyttää yhteisesti sovittuja linjauksia ja niiden noudattamista. Tämän toi esiin myös kehittämispäällikkö Henriikka Mustajoki Tieteellisten seurain valtuuskunnasta (TSv). Hän totesi puheenvuorossaan avoimen tieteen ja tutkimuksen kehittämistyön kuuluvan kaikille. Siksi yhteistyön koordinoiminen onkin erittäin tärkeää ja esimerkiksi Suomessa kyseinen vastuu on siirretty ministeriöltä TSV:lle. Silti varsinainen toimeenpanovastuu jää koko tutkimusyhteisölle, jonka toimijat sitoutuvat edistämään yhteisiä tavoitteita omissa organisaatioissaan.

Vaikka koordinaation täytyy lähteä paikallisista tarpeista ja tavoitteista, tarvitaan Mustajoen mukaan myös kansallisella ja kansainvälisellä tasolla tapahtuvaa yhteistyötä. Conosc (Council for National Open Science Coordination) on vuonna 2019 perustettu Euroopan kansallisten avoimen tieteen koordinaatioiden yhteistyöverkosto. Sen tarkoitus on auttaa maita luomaan, kehittämään ja koordinoimaan kansallisia avoimen tieteen linjauksia ja toimintoja. Verkosto kerää yhteen avointa tiedettä koordinoivia toimijoita, ja mahdollistaa näin yhteisten päämäärien edistämisen myös kansainvälisellä tasolla.

Emma Harris Berliinin Max Delbrück Centrestä pohti keinoja, kuinka tutkijat saataisiin laajemmin mukaan avoimeen tieteeseen. Hän kertoi ORION Open Science -hankkeesta, jossa online-kurssia suunniteltaessa pyrittiin ottamaan huomioon tutkijoita motivoivia ja avoimen tieteen ja tutkimuksen hyötyjä korostavia tekijöitä. Harris totesi, että pelkkä avoimeen tieteen ideologiasta kertominen ei riitä: tarvitaan myös ammatillisia ja konkreettisia hyötyjä korostavaa otetta ja vastauksia kysymykseen miksi. Esimerkiksi avoi-
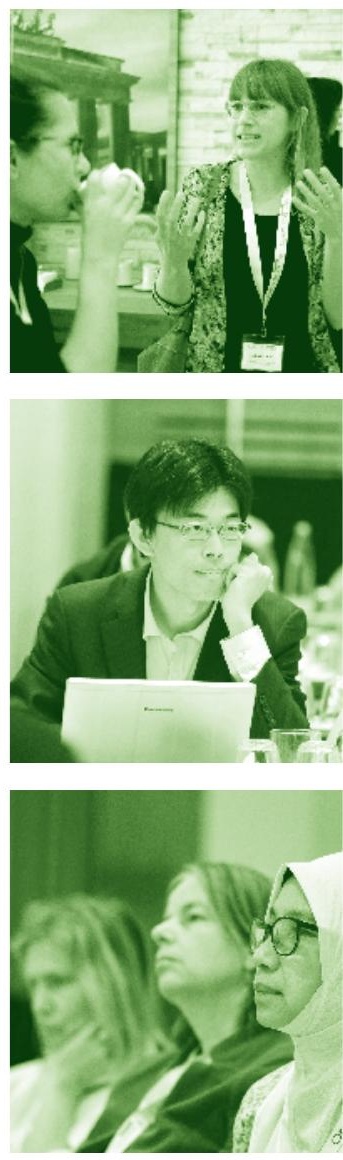

ה Kuvat: Ralf Rebmann (CC-BY-SA 4.O)

\footnotetext{
«Osa puheenvuoroista pidettiin etäyhteyden

avulla ja siksi myös yleisökysymysten esittäminen

poikkesi totutusta.

Kuva: Ralf Rebmann (CC-BY-SA 4.0)
} 
muus voi lisätä viittauksia, terävöittää tieteellistä profiilia, parantaa yhteistyötä ja rahoitusmahdollisuuksia.

Harrisin mukaan tarvitaan myös vastauksia kysymykseen kuinka. Tarvitaan konkreettisia työkaluja kuten tietokantoja, arkistoja, tiedettä popularisoivia tahoja, tunnisteita, tutkimustietovarantoja ja erilaisia välineitä, kuten Unpaywall, Zenodo, ScienceMatters, Jupyter Notebooks, Orcid, rezdata ja preprints. Myös vertaisoppimiseen kannustaminen sekä konkreettisten ja saavutettavissa olevien tavoitteiden asettaminen on oleellista.

\section{Mistä toimintakulttuurin muutos lähtee liikkeelle?}

Avoimen tieteen ja tutkimuksen hyviä käytänteitä ja haasteita organisaatiotasolla on tutkittu jo jonkin verran. Julia Stewart Lowndes NCEAs:ta (National Center for Ecological Analysis and Synthesis) kertoi, kuinka tutkijat suhtautuvat usein myönteisesti avoimeen tieteeseen, mutta käytännössä kamppailevat osaamattomuuden ja kotikutoisten menetelmien kanssa. Vastauksena tutkijoiden tarpeisiin Stewart Lowndes on ollut perustamassa Openscapes-alustaa, joka tarjoaa tukea ja yhteistyöskentelyn mahdollisuuksia. Tavoitteena on, että Openscapesin avulla tutkijat kehittyvät data-osaajiksi ja levittävät tietoa, osaamista ja suotuisaa avoimen tieteen ilmapiiriä omassa organisaatiossaan.

Helene Brinken Göttingenin yliopiston kirjastosta kertoi FIT4RRI-hankkeesta. Sen tavoitteena on löytää erilaisia avoimen tieteen ja vastuullisen tutkimuksen ja innovoinnin trendejä, esteitä ja kannustimia. Esitys perustui hankkeessa tehtyyn kattavaan kirjallisuuskatsaukseen (Fostering Improved Training Tools for Responsible Research and Innovation: Report on the Literature Review) ja neljään case-tutkimukseen. Analyysi paljas-
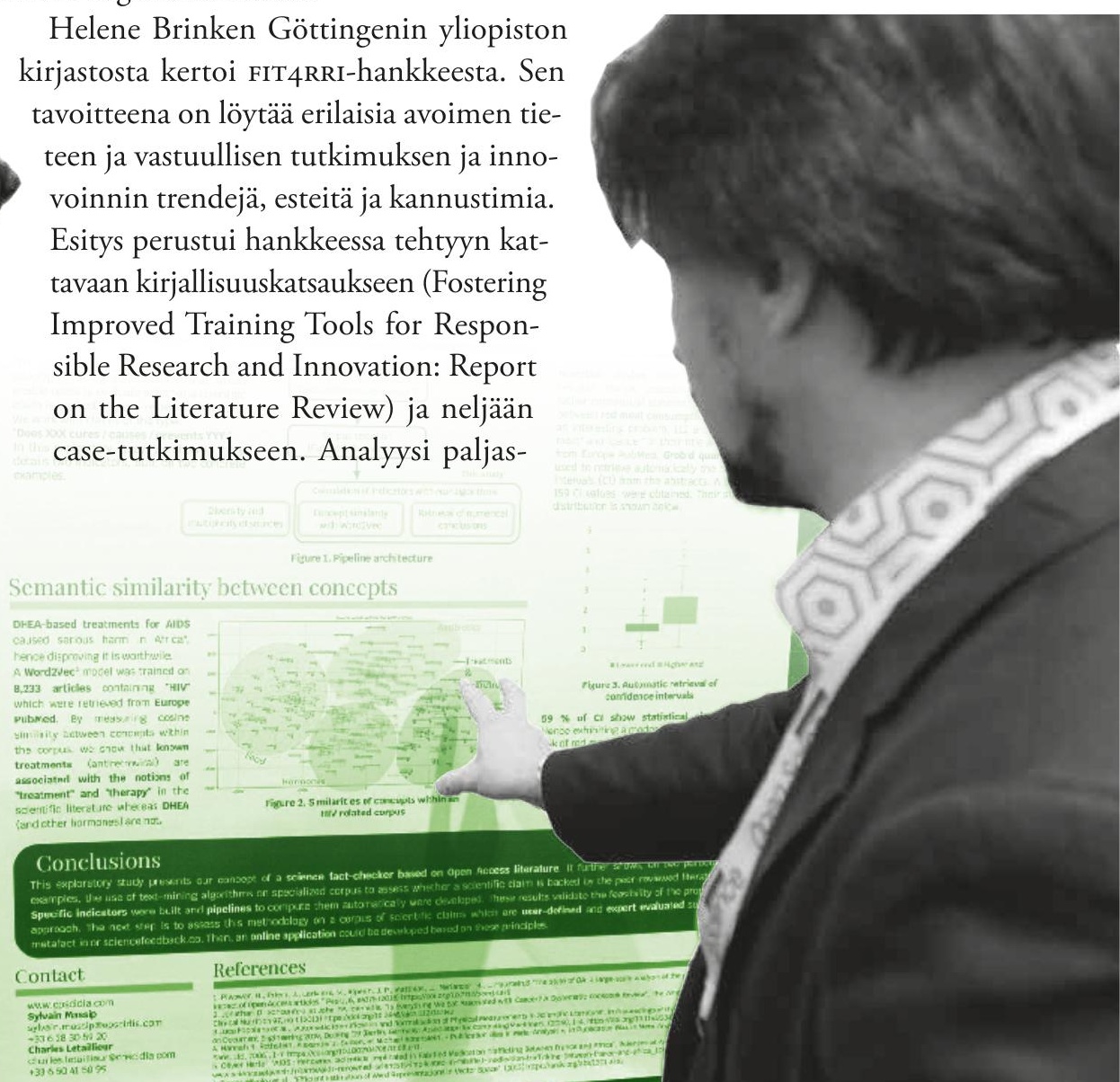
ti seitsemän erilaista viitekehystä (läpinäkyvyys, laatu, mahdollisuuksien lisääminen, demokratia, viestintä, ennakointi ja yhteiskunnalliset tarpeet), joita voidaan käyttää, kun halutaan jalkauttaa avoimen ja vastuullisen tieteen toimintatapoja organisaatioon ja perustella niiden tarpeellisuutta.

Brinken kertoi, että yhtenä keskeisenä tieteellistä tutkimusta muokkaavana trendinä nousi esiin tieteellisen tutkimuksen yhä kiihtyvä kilpailu resursseista. Avoimuuden esteet liittyvät muun muassa asenteisiin, osaamiseen ja siihen, että avoimien toimintatapojen tehokkuutta epäiltiin. Avoimuuden kannustimet puolestaan löytyivät PESTE-analyysin avulla muun muassa taloudellisista ja poliittisista ohjausmekanismeista sekä yhteiskehittämistä edistävistä teknologioista. Brinken toivoi, että tuloksista on apua niille, jotka haluavat jalkauttaa avoimen, vastuullisen tutkimuksen ja innovoinnin toimintatapoja omaan organisaatioon ja ottaa mallia parhaista käytännöistä.

\section{Avoin tiede mukaan varsinaiseen opetukseen}

Sharon Hanna British Columbian yliopiston kirjastosta esitteli kirjaston ja biologian tutkinto-ohjelman yhteisprojektia. Siinä luotiin yhdeksän avoimen tieteen ja tutkimuksen eri osa-alueita käsittelevää moduulia, jotka sijoitettiin sopiviin kohtiin opintoja ja olemassa olevia opintojaksoja. Hannan pääviesti oli, että mitä varhaisemmassa vaihees-

«Posterisessio herätti laajaa

kiinnostusta

Kuva: Ralf Rebmann

(CC-BY-SA 4.O). sa avoimen tieteen käytännöt saadaan integroitua opetukseen, sitä todennäköisemmin ne tulevat käyttöön jatkossa. Sharon totesi myös, että toistaiseksi avoimen tieteen integroiminen opetukseen on vielä aktiivisten henkilöiden varassa ja laajempi organisaatiokohtainen sitoutuminen puuttuu.

\section{Avoimuutta}

\section{yritysyhteistyöhankkeissa}

kateeminen näkökulma ko-
rostui konferenssissa, vaikka
korkeakoulujen tutkimus- ja kehittämistoimintaan osallistuu myös yrityksiä tai työelämän edustajia. Seliina Päällysaho Seinäjoen ammattikorkeakoulusta esitteli erilaisia aineistojen ja tulosten avaamiseen liittyviä haasteita, joita on tunnistettu yritysyhteistyöhankkeissa tutkimusprosessin elinkaaren eri vaiheissa. Parhaimpia käytäntöjä ovat muun muassa luottamuksellisen ilmapiirin luominen, aineistonhallintasuunnitelman teko yhteistyössä, aineiston omistajuudesta ja käytöstä sopiminen sekä lisensointi.

Pälllysaholle kohdistetuissa yleisökysymyksissä kiinnosti erityisesti, millaista käyttökelpoista tutkimustietoa pelkkien tutkimusjulkaisujen lisäksi voitaisiin tuottaa. Keskustelussa pohdittiin, miten tutkimustulosten muotoilu tulisi tehdä ja kenen sitä pitäisi tehdä. Tutkijoiden omaa osaamista tieteen popularisoinnissa kyseenalaistettiin ja tehtävään kaivattiin pikemminkin viestinnän ammattilaisia. Edes asiantuntijat eivät aina ymmärrä vieraan tutkimusalan termejä ja kielimuurin korkeutta tavallisen kansalaisen näkökulmasta voi vain arvailla. 


\section{Lopuksi}

Konferenssin anti oli monipuolinen ja se antoi hyvän kuvan avoimen tieteen tilasta Euroopassa. Konferenssin typistyminen yksipäiväiseksi tapahtui yllättäen, mutta siitä huolimatta tapahtuma vietiin onnistuneesti läpi. Etänä esityksiä seuraavan oli helppo saada katsaus avoimen tieteen nykytilaan hyvinkin ilmastoystävällisesti.

Yhteenvetona voi todeta, että avoimen tieteen käytäntöön viemisessä on edelleen haasteita. Ne liittyvät niin avoimuuden kannustimiin, tutkimusprosessien läpinäkyvyyteen kuin tutkimusaineistojen potentiaalin hyödyntämiseen.

\section{Tietoa kirjoittajista}

ANNE KÄRKI

Satakunnan ammattikorkeakoulu anne.karki@samk.fi

\section{Hannu Hyyppä}

Aalto-yliopisto

hannu.hyyppa@aalto.fi
Selitna PäÄllysaho

Seinäjoen ammattikorkeakoulu seliina.paallysaho@seamk.fi

\section{JAANA LATVANEN}

Seinäjoen ammattikorkeakoulu jaana.latvanen@seamk.fi

Pauli Assinen

Helsingin yliopisto

pauli.assinen@helsinki.fi

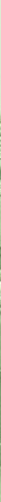

